\title{
The EU Enlargement and Income Convergence: Central and Eastern European Countries vs. Western Balkan Countries
}

\author{
Nenad Stanišić, Nikola Makojević, Tijana Tubić Ćurčić
}

\begin{abstract}
A B S T R A C T
Objective: This article analyses the stochastic convergence of income per capita between the Western Balkan (WB) and the Central and Eastern European (CEE) countries compared to developed EU countries (EU15).

Research Design \& Methods: Stochastic convergence implies that all shocks in country's income relative to the average income of the group are only temporary. In order to test stochastic convergence, the tests of the unit root were used. The Augmented Dickey-Fuller (ADF) test is supplemented with the Zivot-Andrews (ZA) unit root test, which allows for the structural breaks in time series of income per capita.
\end{abstract}

Findings: Results confirm the existence of stochastic convergence of income per capita toward the EU15 average in the cases of the Czech Republic, Slovakia, Poland, Slovenia, Estonia, Latvia and Romania. Income convergence is not found in the case of the Western Balkan countries.

Implications \& Recommendations: While income convergence toward the EU15 average level was found in the case of 7 CEE countries, it was not found in the case of any WB country. This could be a proof of the importance of further support to reforms in the Western Balkan countries.

Contribution \& Value Added: The scientific contribution of the article is reflected in the fact that the existing literature dealing with income convergence of the Western Balkan countries toward the income of the EU15 countries is still very limited in number, as is the number of studies that compare convergence of income per capita toward the EU15 between the Western Balkan and CEE countries.

\begin{tabular}{ll}
\hline Article type: & research paper \\
Keywords: & income convergence; transition economies; European Union; unit \\
& root tests
\end{tabular}

JEL codes: O47, P27, F43

Received: 19 January 2018 Revised: 27 April 2018 Accepted: 17 May 2018

\section{Suggested citation:}

Stanišić, N., Makojević, N., \& Tubić Ćurčić, T. (2018). The EU Enlargement and Income Convergence: Central and Eastern European Countries vs. Western Balkan Countries. Entrepreneurial Business and Economics Review, 6(3), 29-41. https://doi.org/10.15678/EBER.2018.060302 


\section{INTRODUCTION}

In the last few decades, one of the macroeconomic issues that has become increasingly important is whether convergence exists between countries - defined as the process of reducing differences in income per capita over time and whether poorer countries can catch up with richer countries in terms of the standards of living. The theoretical importance and the interest in this issue derive from the fact that testing for the existence of convergence presents the answer that confirms the validity of one out of two alternative theoretical approaches (Islam, 2003). While income convergence is an integral part of the neoclassical growth model (Solow, 1956), new theories of growth - theories of endogenous growth - imply that convergence does not occur automatically when the countries differ in income levels and that additional factors determine the existence of the convergence process (Romer, 1986; Lucas, 1988). In addition to different predictions regarding convergence, recommendations for conducting regional policies are also different (Hofer \& Worgotter, 1997). New theories of economic growth advocate the idea that economic policies can influence not only the level of production, as discussed in the traditional neoclassical theory, but also the equilibrium rate of economic growth.

The rapid growth of poorer countries in comparison with their richer counterparts and a decrease in disparity in income per capita in the neoclassical growth model, is the result of the decreasing rate of return on capital, due to the fact that the marginal product of capital in poor countries, with smaller income per capita, is higher compared to richer regions with a higher volume of capital per capita (Cherodian \& Thirwall, 2015). Income per capita converges towards various equilibrium stages (conditional convergence) or towards a mutual equilibrium stage (absolute convergence), independently from the initial level of income. The differences in equilibrium income between countries reflect differences in the rate of savings, the growth rate of population and the capital depreciation rate (Miller \& Upadhuay, 2002). Supporters of the theories of endogenous growth reject the assumption of decreasing returns and faster growth of poor countries compared to the more affluent ones and stress that returns are either constant or growing. Due to growing income, production activity will be concentrated in a certain number of countries and inequalities in development will be intensified - divergence between countries will appear.

Europe consists of heterogeneous countries which have significant disparities in income per capita, so the question of convergence or the possibility of decreasing economic inequalities is a key economic and political challenge (Sutherland, 1986). During the last 25 years, significant transformations have taken place in ex-communist European countries, which have resulted in their integration into the global economy and an increase in living standards. However, for the first several years of transition towards the market economy framework, reforms of political and regulatory systems were followed by a drastic decrease in output, high inflation and an increase in the unemployment rate in these countries (Fisher, Sahay, \& Vegh, 1998; Fisher \& Sahay, 2000). An initial recession period was followed by divergence in income per capita between socialist countries and the rest of Europe, as well as within the countries themselves. In all countries, the transition towards a market economy was accompanied by numerous issues. However, countries in the Western Balkans (WB) had particular difficulties, where, due to war, political instability, sanctions, economic instability and isolation, the transition process began a decade later compared to the 
other countries of Central and Eastern Europe (CEE). Despite economic progress in the last 15 years, which is reflected in an increase of gross domestic product (GDP), GDP per capita and convergence of income between the WB countries and developed EU countries, the speed at which reforms have been implemented is insufficient, hence, the entire region has still not completed the transition process (Stanišić, 2016).

In order to gain initial insight into the development of the WB countries thus far and the comparative disparity with EU member states, the dynamics of the change in the GDP per capita in these countries for the period 1993-2015 was analysed. Figure 1 depicts the trends of average GDP per capita measured by purchase power parity (PPP) in the EU15 (Germany, France, Italy, Netherlands, Belgium, Luxembourg, United Kingom, Denmark, Ireland, Greece, Spain, Portugal, Austria, Sweden and Finland), the CEE10 (Poland, Czech Republic, Slovakia, Slovenia, Hungary, Latvia, Lithuania, Estonia, Romania and Bulgaria) and the WB countries (Croatia, Bosnia and Herzegovina, the Republic of Serbia, Montenegro, FYR Macedonia and Albania).

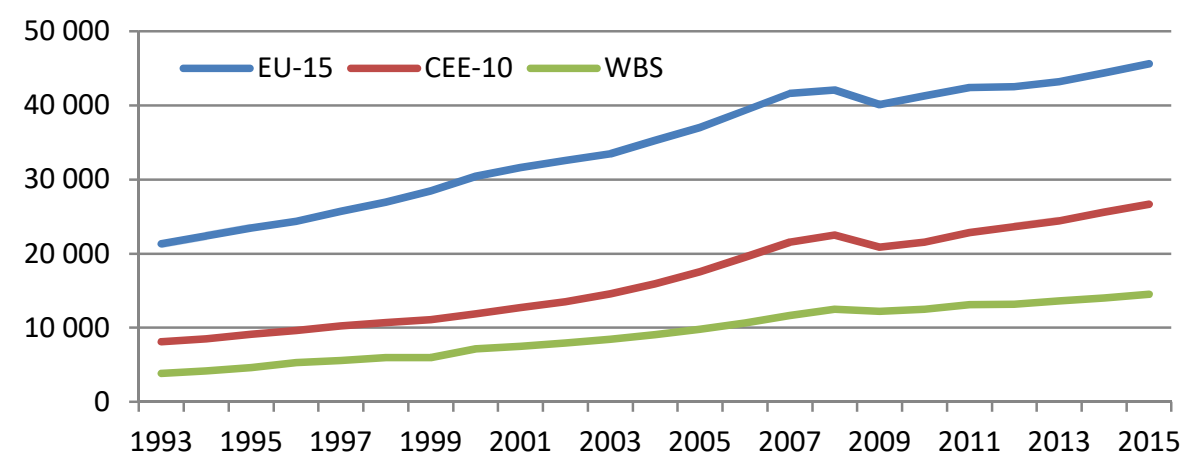

Figure 1. Trends of average GDP per capita (PPP) in EU-15, CEE-10 and WB, in the period 1993-2015, in current international dollars

Source: World Economic Outlook (2016).

The level of living standards, measured by average GDP per capita, increased in all three groups of countries observed. The prosperity which characterised European transition countries at the beginning of the 21st century was suddenly halted due to the beginning of the global financial crisis, primarily in new EU countries. The crisis demonstrated that growth was not sustainable in many countries. In the long run, the manner in which economic growth is generated is important and not only via sudden increases in production. The lowest standards of living were found in the WB countries. In 2015, the standard of living was two times lower compared to that in the CEE10 countries and three times lower than in developed EU countries (EU15). The gap in GDP per capita between these groups of countries can be attributed to constantly lower productivity, higher unemployment and lower levels of human capital and competitiveness in the WB region (Holzner, 2016).

Based on these facts, the subject of the research is the convergence of income of the CEE and WB countries toward the average income per capita of developed EU countries. The aim of the research is to examine, through theoretical and empirical analysis, whether 
the CEE and WB countries are converging towards developed countries in terms of income per capita. In line with this, the following research hypothesis is going to be tested:

The Western Balkan and Central and Eastern European countries are converging to the EU15 in terms of income per capita.

The article consists of five sections. Firstly, the results of relevant empirical research on the convergence of income are presented. There then follows an explanation of the data used and the applied methodology of the research, with the results of the research then presented. Lastly, the conclusions of the article are summarised and further direction for research in the area is outlined.

\section{LITERATURE REVIEW}

As a topic of scientific research, the income per capita convergence between different countries has increased in importance since the appearance of the so-called "controversy on convergence", which arose as a result of theoretical and scientific debate after the appearance of the theory of endogenous growth (Azzoni, 2001). In literature, the question of convergence has been analysed in various manners. Papers that analyse convergence can be divided into two groups (Bernard \& Durlauf, 1996). The first group of authors use cross-sectional data analysis, in order to examine dependence between the income growth rate from its initial level and proved hypotheses on convergence, whereas the other group uses the approach of time series. The time series approach uses unit root tests in order to prove hypotheses related to convergence. The use of various methods and the analysis of different time frames have resulted in mixed conclusions. For this reason, the question of convergence in real income per capita between European countries is still a highly controversial topic.

Cross-sectional studies mainly confirm the existence of the convergence of income. Matkowski and Prochniak (2004) examined the convergence of income between CEE countries (CEE8) and 'old' EU members, as well as in CEE8 countries themselves. The authors confirmed the existence of convergence for eight new member states, as well as a decrease in the gap in development compared to the EU15 members. A later study, conducted by the same authors using the same sample three years later but over a longer timeframe, confirms the existence of income convergence between 'old' and 'new' EU members (Matkowski \& Prochniak, 2007). A decrease in the gap in development between 'old' and 'new' EU members was confirmed in the papers of Kaitila (2004); Vojinovic \& Oplotnik (2008); Vojinovic, Acharya, \& Prochniak (2009); Rapacki \& Prochniak (2009); Vojinovic, Oplotnik, \& Prochniak (2010); Głodowska (2015).

The different results of these papers are demonstrated in the speed of the convergence. The existence of convergence between new members and the EU15, as well as huge differences in the speed of convergence was asserted in the papers of Vamvakidis (2008) and Cavenaile and Dubois (2011). Szeles and Marinescu (2010) confirm the existence of absolute and conditional convergence in CEE countries. A decrease in the gap in development between the CEE10 and the EU15 countries was confirmed by Stanišić (2012), with the negative impact of the global financial crisis affecting the speed of convergence.

The approach of using time series in order to prove the existence of convergence started in the last decade of the 20th century. Some of these studies which based their 
analysis on this approach include Kutan and Yigit (2005), who analysed stochastic convergence and proved the existence of significant progress of new members in convergence towards the EU. Brüggemann and Trenkler (2007) compared the convergence in income per capita between the Czech Republic, Hungary, Poland and the EU15 economies. The results demonstrated that stochastic convergence existed only between the Czech Republic and the EU15 countries. Cunado and Perez de Grazia (2006) proved a decrease in the gap in the standard of living of Poland, the Czech Republic and Hungary compared to the German economy in the period between 1990 and 2003. Kocenda, Kutan and Yigit, (2006) and Ingianni and Zdarek (2009) proved a decrease in income divergence among new members was present, as well as between new and old members, accentuating that differences exist among countries in the speed of catching up living standards, compared to developed EU members. Reza and Zahra (2008) confirmed the existence of absolute convergence, but not conditional convergence of income per capita between new and developed EU members. The process of the catching up between new and old members was confirmed in the papers of Gligoric (2014) and Strielkowski and Hoschle (2016), who analysed convergences in income in the EU during the last few decades of expansion and they found proof of the existence of convergence within the EU.

Although studies on income convergence of new EU members are numerous, there are few studies concerning the convergence between the Western Balkan countries and the EU15. El Ouardighi and Somun-Kapetanovic (2007) analysed the process of income per capita convergence between the WB countries and the EU24 during the period 19892005. They confirmed that after an increase in the gap in development between the two groups of countries during the period 1991-1993, the gap decreased but remained very significant, and the process of convergence with the EU remained very slow. Tsanana, Katralikidis and Pantelidis (2012) analysed income convergence between Balkan countries and the EU15 and concluded that it could be confirmed only in the cases of Slovenia and Greece, but not in the case of other Balkan states. Two years later, Tsanana and Katralikidis (2014) used unit root tests to prove the existence of income convergence among countries in the Balkans, as well as between these countries and the EU, remarking that although all WB states recovered after the year 2000, most of the countries were hit by the global economic crisis and therefore the convergence of their income toward average income of the EU countries remains under question.

A study of the International Monetary Fund (Murgasova, Ilahi, Miniane, Scott, \& Vladkova-Hollar, 2015) examined the speed at which new member states of the EU (NMS) and the WB countries catch up the average GDP per capita of developed EU members (EU15). It was concluded that a very slow convergence between WB and the EU15 countries was achieved in the period 2000-2007, explained by the fact that the growth of less developed countries such as Bosnia and Herzegovina and Albania was slower compared to developed countries like Croatia. In the same period, significant convergence of income between NMS and the EU15 was achieved. After the beginning of the economic crisis, authors proved the existence of convergence for the WB countries, although slower than achieved by NMS countries. Stanišić (2016) tested the speed and existence of convergence of income in the Western Balkans countries and developed EU countries, compared to NMS. The results suggested that although convergence was achieved in the pre-crisis years, the global financial crisis halted the decrease in the gap in the economic 
development between the EU15 and the WB countries, while at the same time the income gap between the WB countries and NMS increased.

A study of the European Investment Bank (Berthomieu, Cingolani, \& Ri, 2016) demonstrated that although the gap in the standards of living between countries in the Western Balkans and the EU15 is decreasing, it is still very high. A period of at least twenty years will need to pass for the region to achieve the income per capita of the EU15, unless the growth rate of the Western Balkan countries were to increase to $6 \%$ per year, while being at a level of $1 \%$ in the EU15. If the growth rate of the WB countries were smaller, i.e. $4 \%$ per year, 14 years or more would be needed to achieve equal standards of living.

The scientific contribution of this article is reflected in the fact that there are few studies on income convergence between the Western Balkan countries and the EU15, as is the number of studies that compare convergence of income per capita toward the EU15 between WB and the CEE10 countries.

\section{MATERIAL AND METHODS}

There are two main methodological approaches to test the existence of income convergence. One is based on cross-sectional analysis of panel data, while the other one is based on time-series analysis. Since Friedman (1992) criticised the cross-sectional approach of testing the impact of initial level of income on the rate of economic growth, there is an increasing number of researchers who explores the existence of income convergence based on time-series analysis. This approach examines the existence of so called 'stochastic convergence', as first time described in Carlino and Mills (1993). Stochastic convergence implies that all shocks in country's income relative to the average income of the group which a country belongs to are only temporary. In accordance with that, econometric tests of stochastic convergence are based on unit root test applied to time series of natural logarithm of a country's income relative to the average countries group income. The rejection of null hypothesis of unit root in time-series is considered as a proof of income convergence, and vice versa.

This article examines the existence of stochastic income convergence among the Western Balkan states (WBS) and New EU member states (Central and East European countries, CEE10) on the one hand, and the most developed members of the EU (EU15), on the other hand.

Econometric approach of testing the income convergence is based on differentiation between two types of non-stationarity of time-series with a trending mean, which are:

1. Trend stationary: The mean trend is deterministic. Once the trend is estimated and removed from the data, the residual series is a stationary stochastic process,

2. Difference stationary: The mean trend is stochastic. Differencing the series $D$ times yields a stationary stochastic process.

The distinction between a deterministic and stochastic trend has important implications for the long-term behaviour of a process:

1. Time series with a deterministic trend always revert to the trend in the long run (the effects of shocks are eventually eliminated),

2. Time series with a stochastic trend never recover from shocks to the system (the effects of shocks are permanent), which is why there is no convergence. 
In order to examine the existence of stochastic income convergence, two different unit root tests are used in this article: Augmented Dickey-Fuller (ADF) test and ZivotAndrews (ZA) test of unit root.

The augmented Dickey-Fuller tests if a variable follows a unit-root process. The null hypothesis is that the variable contains a unit root, and the alternative is that the variable was generated by a stationary process. Giving the fact that time-series of income of the WBS and the CEE10 relative to the EU15 average income over time have trend, ADF test that includes the trend is used.

The main drawback of ADF unit root test is that it ignores the existence of structural breaks in time-series, which could be of high importance in income time-series analysis. Therefore, Zivot and Andrews (1992) suggest the utilisation of unit root test which allows a single break in intercept and/or trend. As the existence of structural changes and shocks is common for the process of economic transition in the WBS and the CEE10 countries, ADF test is supplemented with the ZA unit root test in this article. If potential structural changes are not allowed for in the specification, but are, in fact, present, the results may be spurious because they can be biased towards the non-rejection of the non-stationarity hypothesis (Perron \& Zhu, 2005).

The following equation that allows one time change in both the level and the slope of the series is estimated to test for the unit root:

$$
x_{i}=\alpha_{0}+\alpha_{1} D U_{i}+d(D T B)_{i}+\gamma(D T)_{i}+\beta t+\rho x_{t-1}+\sum\left(\phi_{i} \Delta x_{t-1}\right)+e_{i}
$$

Where the intercept dummy $D U_{t}$ represents a change in the level $\left(D U_{t}=1\right.$ if $t>T B$, and zero otherwise); the slope dummy $D T_{t}$ represents a change in the slope of the trend function $\left(D T_{t}=t\right.$ if $t>T B$, zero otherwise); $D T B_{t}$ is the crash dummy $\left(D T B_{t}=1\right.$ if $t=T B+1$, and zero otherwise); and $T B$ is the break date; $t$ is the time trend variable, while $\Delta$ denotes the first difference. The model has a unit root with a break under the null hypothesis. The alternative hypothesis is a broken trend stationary process.

The data used for the theoretical and empirical analysis were taken from a data base of World Economic Outlook (2016) and cover the period 1993-2015. As a measure of income per capita, quarterly data on real GDP per capita in the countries of the Western Balkans, the Central and Eastern European countries (CEE10), and developed EU countries (EU15) were used, adjusted by purchasing power parity of the currency.

\section{RESULTS AND DISCUSSION}

Table 1 summaries the results of Augmented Dickey-Fuller test of unit root in timeseries with trend and with one year time lag.

Based on the ADF unit root test results, the income convergence toward the average income of the EU15 countries is proved only in the following three cases: Slovenia and Latvia from the CEE10 group of countries, and Bosnia and Herzegovina from the WB group. In all other cases it was not possible to reject null hypothesis of the existence of unit root in income ratio time-series.

As the economic transition process in all countries of both the CEE10 and the WBS groups was marked with structural shocks, more reliable results are expected from ZA unit root test which allows for endogenous break in time-series. Table 2 summarises the results of ZA test, with breaks in trends and intercepts allowed. 
Table 1. ADF test results

\begin{tabular}{|c|c|c|}
\hline country & t-statistics & p value \\
\hline \multicolumn{3}{|l|}{ CEE10 } \\
\hline Bulgaria & -2.997 & 0.13 \\
\hline Czech R. & -2.337 & 0.41 \\
\hline Estonia & -2.999 & 0.13 \\
\hline Hungary & -2.382 & 0.38 \\
\hline Latvia & $-3.136 *$ & 0.09 \\
\hline Lithuania & -2.121 & 0.53 \\
\hline Poland & -1.676 & 0.76 \\
\hline Romania & -2.484 & 0.33 \\
\hline Slovak R. & -2.434 & 0.36 \\
\hline Slovenia & $-3.739 * * *$ & 0.01 \\
\hline \multicolumn{3}{|l|}{ WBS } \\
\hline Croatia & -1.950 & 0.62 \\
\hline Bosnia and Herzegovina & $30.330 * * *$ & 0.00 \\
\hline Serbia & -1.969 & 0.61 \\
\hline Montenegro & -1.790 & 0.70 \\
\hline FYR of Macedonia & -2.062 & 0.56 \\
\hline Albania & -2.758 & 0.21 \\
\hline
\end{tabular}

Note: Boundary value of t-statistics for $10 \%$ significance is -3.240 , for $5 \%$ significance it is -3.600 , and for $1 \%$ significance it is -4.380

Source: own study.

Table 2. Results of ZA unit root test

\begin{tabular}{|r|l|l|}
\hline \multicolumn{2}{|c|}{ country } & \multicolumn{2}{|c|}{ Break year } \\
\hline CEE10 & \multicolumn{2}{|c|}{} \\
\hline Bulgaria & -2.993 & 2011 \\
\hline Czech R. & $-5.379^{* *}$ & 1997 \\
\hline Estonia & $-5.982^{* * *}$ & 1997 \\
\hline Hungary & -3.173 & 2002 \\
\hline Latvia & $-5.792^{* * *}$ & 2005 \\
\hline Lithuania & -3.172 & 2003 \\
\hline Poland & $-3.767^{*}$ & 2001 \\
\hline Romania & $-5.093^{* *}$ & 1997 \\
\hline Slovak R. & $-4.334^{* *}$ & 1999 \\
\hline Slovenia & $-5.951^{* * *}$ & 2008 \\
\hline WBS & & 2002 \\
\hline Bosnia and Herzegovina & -3.170 & 2008 \\
\hline Serbia & -3.263 & 2012 \\
\hline Montenegro & -2.447 & 2007 \\
\hline FYR of Macedonia & -3.950 & 2001 \\
\hline Albania & -3.204 & 1997 \\
\hline
\end{tabular}

Note: Boundary value of t-statistics for $10 \%$ significance is -4.82 , for $5 \%$ significance it is -5.08 , and for $1 \%$ significance it is -5.57

Source: own study. 
ZA unit root test results confirm the existence of stochastic income convergence in all CEE countries except Bulgaria, Hungary, and Lithuania. In all other cases the existence of unit root in time-series of relative income is confirmed. No convergence was proven within the WBS group.

Compared to ADF unit root test results, the number of the countries for which the income convergence can be confirmed in the case of ZA unit root test is higher: seven compared to three. Beside Slovenia, and Latvia, the stochastic income convergence can be confirmed also in the cases of Czech Republic, Slovakia, Poland, Estonia, and Romania as well.

Looking at the years of breaks in time-series, it is possible to conclude that these years are mostly from 1990s transition period, or from the recent financial and economic crisis.

Income convergence towards an average level of income of the EU15 in the identified CEE countries is due to a number of reasons. The main reasons why the Czech Republic, Slovakia, Poland, Slovenia, Estonia and Latvia are catching up with the living standards of developed European economies could be found in a relatively short and successful period of the transition process, as well as in the quality of institutional reform. The intensive inflow of direct foreign investment in these economies could be one of the reasons for their faster convergence. This factor is considered one of the most crucial for a decrease in the developmental gap in Romania, compared to developed EU countries. In contrast, convergence in Bosnia and Herzegovina (proven only by ADF test) is probably the result of significantly low income at the beginning of the observed period due to the civil war.

The results obtained in this article are generally in line with findings in the existing literature, especially for the CEE countries, although obtained with a different research method. Comparable results obtained with different methodological approaches serve as a kind of proof of robust income convergence between almost all CEE countries and the EU15. As far as the Western Balkan states are concerned, results are in line with Tsanana, Katralikidis and Pantelidis (2012), and Tsanana and Katralikidis (2014), where the income convergence between WB states and the EU15 were not found. Even studies that have shown convergence in income between WB states and the EU15 found it to be very slow, as in Murgasova et al. (2015).

\section{CONCLUSIONS}

The basic expectation for European transition economies after the initiation of the transition process and the EU accession was in reaching the standards of living enjoyed by developed European economies. In accordance with this, the subject of the analysis within this article is the examination of stochastic income convergence between the Western Balkan and the Central and Eastern European countries on one side, and developed EU countries (EU15) on the other side, in the period 1993-2015. The examination of income convergence between European countries is important from the aspect of analysing the achieved success and overlooking differences in the level of income per capita in Europe.

The scientific contribution of the article is reflected in the fact that the existing literature dealing with income convergence of the Western Balkan countries toward income of the EU15 countries is still very limited in number, as is the number of studies that compare convergence of income per capita toward the EU15 between the Western Balkan countries and new EU members (CEE10). Also, research on stochastic convergence between the Western Balkan countries and developed EU15 is barely in existence. 
In order to examine the stochastic convergence of income, an approach based on time series was applied in the article. Two unit root tests were used: the Augmented DickeyFuller (ADF) test and the Zivot-Andrews (ZA) test. The results of the ADF test demonstrate the existence of income convergence towards the average level of income of developed EU countries only in the case of three countries: two from the CEE10 group - Slovenia and Latvia, and one from the WB group - Bosnia and Herzegovina. In all other cases, it was not possible to reject null hypothesis on the existence of a unit root test in a time series of income ratio of the country and average income of the EU15. Due to the fact that the transition process in the CEE10 and the Western Balkan countries was characterised by significant structural changes and shocks, an addition to the ADF test, the ZA test was also used, with endogenous breaks in the time series permitted. The results of this test demonstrate that income convergence exists in the case of seven countries, all from the CEE10 group; the Czech Republic; Slovakia, Poland, Estonia; Latvia, Romania and Slovenia. In all other cases, a null hypothesis of the unit root test was confirmed. The income convergence toward the EU15 was not confirmed for any Western Balkan country.

According to the results obtained, the hypothesis that a convergence of income toward the EU15 average level exists among the CEE10 and the WB countries can be only partially accepted. The absence of convergence in the case of any WB state could be a proof of the importance of further support to reforms in the Western Balkan countries, whose economies are still very vulnerable to economic shocks, both internal and external.

The main research limitation of the article is the relatively short period of the observed time, and even more importantly the fact that the Western Balkan countries were faced with many social and political issues, and even conflicts during the 1990s, which greatly influenced their income.

The research conducted suggests several options for further development. Above all, a broader insight is necessary to identify factors that determine the existence of convergence and explain why some countries experienced the reduction of development gap, while the other ones did not.

\section{REFERENCES}

Azzoni, R.C. (2001). Economic growth and regional income inequality in Brazil. The Annals of Regional Science, 35, 133-152. https://doi.org/10.1007/s001680000038

Bernard, A.B., \& Durlauf, S.N. (1996). Interpreting tests of the convergence hypothesis. Journal of Econometrics, 71, 61-173. https://doi.org/10.1016/0304-4076(94)01699-2

Berthomieu, C., Cingolani, M., \& Ri, A. (2016). Investment for Growth and Development in the Western Balkans. Nice: EIB Institute

Brüggemann, R., \& Trenkler, C. (2007). Are Eastern European Countries Catching Up? Time Series Evidence for Czech Republic, Hungary and Poland. Applied Economic Letters, 14, 245-249. https://doi.org/10.1080/13504850500425782

Carlino, G., \& Mills, L. (1993). Are U.S. regional economies converging? A time series analysis. Journal of Monetary Economics, 32, 335-346. https://doi.org/10.1016/0304-3932(93)90009-5

Cavenaile, L., \& Dubois, D. (2011). An empirical analysis of income convergence in the European Union. Applied Economic Letters, 18, 1705-1708. https://doi.org/10.1080/13504851.2011.560104 
Cherodian, R., \& Thirwall, A.P. (2015). Regional disparities in per capita income in India: convergence or divergence?. Journal of Post Keynesian Economics, 37, 384-407. https://doi.org/10.1080/01603477.2015.1000109

Cùnado, J., \& Perez de Gracia, F. (2006). Real convergence in some Central and Eastern European countries. Applied Economics, 38, 2433-2441.

El Ouardighi, J., \& Somun-Kapetanović, R. (2007). Do Balkan Countries Have European Future? An Analysis of Real Economic Convergence, 1989-2005. South East European Journal of Economics and Business, 2(2), 23-30. https://doi.org/10.2478/v10033-007-0002-4

Fischer, S., \& Sahay, R. (2000). Transition economies after 10 years. Washington D.C.: International Monetary Fund.

Fischer, S., Sahay, R., \& Vegh, C.A. (1998). From transition to market: evidence and growth prospect. Washington D.C.: International Monetary Fund. https://doi.org/10.2139/ssrn.100268

Friedman, M. (1992). Do old fallacies ever die?. Journal of Economic Literature, 30, 2129-2132.

Gligorić, M. (2014). Paths of income convergence between country pairs within Europe. Economic Annals, 59(201), 123-156. https://doi.org/10.2298/EKA1401123G

Głodowska, A. (2015). Beta and Sigma Convergence within the European Union Countries and Regions. Proceedings of the 6th Global Conference on Management in Recovering Markets, (eds. Alenka Kavkler and Klavdij Logožar), University of Maribor - Faculty of Economics and Business

Hofer, H., \& Wörgötter, A. (1997). Regional Per Capita Convergence in Austria. Regional Studies, 31(1), 1-12. https://doi.org/10.1080/00343409750134746

Holzner, M. (2016). Policy Options for Competitiveness and Economic Development in Western Balkans: the case for Infrastructure Investment. Vienna: The Vienna Institute for International Economic Studies

Ingianni, A., \& Ždarek, V. (2009). Real Convergence in the New Member States: Myth or Reality?. Journal of Economic Integration, 24(2), 294-320. https://doi.org/10.11130/jei.2009.24.2.294

Islam, N. (2003). What have We Learnt from the Convergence Debate?. Journal of Economic Surveys, 17(3), 309-362. https://doi.org/10.1111/1467-6419.00197

Kaitila, V. (2004). Convergence of Real GDP per capita in the EU15. How do the accession countries fit in?. Brussels: European Network of Economic Policy Research Institutes.

Kutan, A.M., \& Yigit, M.T. (2005). Real and Nominal stochastic convergence: Are the new EU members ready to join the Euro zone?. Journal of Comparative Economic, 33, 387-400. https://doi.org/10.1016/j.jce.2005.03.001

Kocenda, E., Kutan, M.A., \& Yigit, M.T. (2006). Pilgrims to the Eurozone: How far, how fast?. Economic System, 30, 311-327. https://doi.org/10.1016/j.ecosys.2006.07.003

Lucas, R.E. (1988). On the mechanics of economic development. Journal of Monetary Economics, 22, 3-42. https://doi.org/10.1016/0304-3932(88)90168-7

Matkowski, Z., \& Prochniak, M. (2004). Real economic convergence in the EU accession countries. International Journal of Applied Econometrics and Quantitative Studies, 1(3), 5-38.

Matkowski, Z., \& Prochniak, M. (2007). Economic Convergence Between the CEE-8 and the European Union. Eastern European Economics, 45(1), 59-76. https://doi.org/10.2753/EEE0012-8775450103

Miller, S.M., \& Upadhyay, M.P. (2002). Total factor productivity and convergence hypothesis. Journal of Macroeconomics, 24(2), 267-286. https://doi.org/10.1016/S0164-0704(02)00022-8

Murgasova, Z., Ilahi, N., Miniane, J., Scott, A., \& Vladkova-Hollar, I. (2015). The Western Balkans: 15 years of economic transition. Washington D.C.: International Monetary Fund 
Perron, P., \& Zhu, X. (2005). Structural breaks with deterministic and stochastic trends. Journal of Econometrics, 129, 65-119.

Rapacki, R., \& Prochniak, M. (2009). The EU Enlargement and Economic Growth in the CEE New member Countries. Brussel: European Commission.

Reza, R., \& Zahra, T.K. (2008). Evaluation of Income Convergence hypothesis in Ten New Member of the European Union. Panel Unit Root Approach. Panoeconomicus, 2, 157-166.

Romer, P.M. (1986). Increasing returns and long-run growth. Journal of political economy, 94, 10021037. https://doi.org/10.1086/261420

Solow, R. (1956). A contribution to the theory of economic growth. Quarterly journal of economics, 70, 65-94. https://doi.org/10.2307/1884513

Stanišić, N. (2012). The effects of the economic crisis on income convergence in the European Union. Acta Oeconomica, 62(2), 161-182.

Stanišić, N. (2016). Income convergence in the process of the Western Balkan States Accession to the European Union. Ekonomski Horizonti, 18(1), 3-14. https://doi.org/10.5937/ekonhor1601003S

Strielkowski, W., \& Höschle, F. (2016). Evidence for economic convergence in the EU: analysis of past EUI enlargements. Technological and Economic Development of Economy, 22(4), 617-630. https://doi.org/10.3846/20294913.2014.890138

Sutherland, P. (1986). Europe and the principle of convergence. Regional Studies, 20, 371-377.

Szeles, R.M., \& Marinescu, N. (2010). Real convergence in the CEECs, euro area accession and the role of Romania. The European Journal of Comparative Economics, 7(1), 181-202.

Tsanana, E., Katralikidis, C., \& Pantelidis, P. (2012). Balkan area and EU-15: An Empirical Investigation of Income Convergence. In A. Karasavvoglou \& P. Polychronidou (Eds.), Balkan and Eastern Countries in the Midst of the Global Economic Crisis, Contributions to Economics, Springer-Verlag Berlin Heidelberg. https://doi.org/10.1007/978-3-7908-2873-3_2

Tsanana, E., \& Katralikidis, C. (2014). Do Balkan economies catch up with EU? New evidence from panel unit root analysis. Empirica, 41(4), 641-662. https://doi.org/10.1007/s10663-013-9222-2

Vamvakidis, A. (2008). Convergence in Emerging Europe: Sustainability and Vulnerabilities. Washington D.C.: International Monetary Fund. https://doi.org/10.5089/9781451870398.001

Vojinović, B., \& Oplotnik, J.ž. (2008). Real convergence in the New EU Member State. Prague Economics Paper, 17(1), 23-39. https://doi.org/10.18267/j.pep.317

Vojinović, B., Acharya, S., \& Prochniak, M. (2009). Convergence analysis among the ten European transition economies. Hitotsubashi Journal of Economic, 50, 123-141.

Vojinović, B., Oplotnik, J.ž., \& Prochniak, M. (2010). EU Enlargement and Real Economic Convergence. Post-Communist Economies, 22(3), 303-322. https://doi.org/10.1080/14631377.2010.498681

Zivot, E., \& Andrews, DWK. (1992). Further evidence on the great crash, the oil-price shock and the unit root hypothesis. Journal of Business and Economic Statistics, 10, 251-270. https://doi.org/10.2307/1391541 


\section{Authors}

The contribution share of authors is equal and amounted to $33 \%$ each of them.

\section{Nenad Stanišić}

Prof. Dr. Nenad Stanišić is an associate professor at the University of Kragujevac, Faculty of Economics. He obtained his PhD in Economics at the University of Belgrade in 2010. His research interests include international integration and international economics.

Correspondence to: Prof. Dr. Nenad Stanišić, Ekonomski fakultet, Đure Pucara Starog 3, 34000 Kragujevac, Serbia, e-mail: nstanisic@kg.ac.rs

\section{Nikola Makojević}

Prof. Dr. Nikola Makojević is an associate professor at the University of Kragujevac, Faculty of Economics. He obtained his PhD in Economics at the Singidunum University in Belgrade in 2011. His research interests include economic development and regional economics.

Correspondence to: Prof. Dr. Nikola Makojević, Ekonomski fakultet, Đure Pucara Starog 3, 34000 Kragujevac, Serbia, e-mail: nmakojevic@kg.ac.rs

\section{Tijana Tubić Ćurčić}

Tijana Tubić Ćurčić, MSc is a teaching assistant at the University of Kragujevac, Faculty of Economics. She obtained MSc degree in Economics at the University of Kragujevac in 2013. Her research interests include international economics.

Correspondence to: Ms. Tijana Tubić Ćurčić, Ekonomski fakultet, Đure Pucara Starog 3, 34000 Kragujevac, Serbia, e-mail: t.tubic@kg.ac.rs

\section{Acknowledgements and Financial Disclosure}

We would like to thank two anonymous reviewers for their valuable suggestions and comments.

\section{Copyright and License}

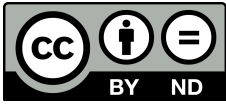

This article is published under the terms of the Creative Commons

Attribution - NoDerivs (CC BY-ND 4.0) License http://creativecommons.org/licenses/by-nd/4.0/

\section{Published by the Centre for Strategic and International Entrepreneurship - Krakow, Poland}


